\title{
The Effect of Need for Achievement and Training on Teacher Performance Through Competence Mediation Variables: Case Study of Vocational School Teachers in Bogor District 2019-2020
}

\author{
David Nehemia $^{1}$, Mafizatun ${ }^{2}$ \\ \{davidnehemia07@gmail.com¹, mafizatunnurhayati69@gmail.com² ${ }^{2}$, \\ Universitas Mercu Buana, Jakarta, Indonesia ${ }^{12}$
}

\begin{abstract}
This study aims to analyze the effect of need for achievement, training on performance with competence mediation variables on vocational teachers in Bogor Regency. The population in this study were vocational school teachers in Bogor Regency, totaling 2975 people. The sample used was 100 people. The sampling technique uses slovin method. Data analysis method uses Structural Equation Model Partial Least Square (SEM PLS). The results found that need for achievement did not affect teacher performance. Training has a positive effect on teacher performance. Need for achievement has a positive effect on teacher competence. Training has a positive effect on teacher competence. Need for achievement has a positive effect on teacher performance through the variable of teacher competence mediation. Training has a positive effect on teacher performance through mediating variables of teacher competence.
\end{abstract}

Keywords: Need for Achievement, Training, Competence, Teacher Performance, SEM PLS

\section{Introduction}

Education in Indonesia is implemented and grouped into several levels. The levels are divided based on the age and ability of students, each level of education has different age and educational time limits. Starting from basic education, secondary education, and higher education. This is clearly regulated in Law number 20 of 2003 in articles 17, 18 and 19[1]. The phenomenon that occurs in SMK is the low performance of teachers according to the data and statistics center of the ministry of education and culture. One of the factors behind the emergence of these problems is caused by the lack of competence that links and matches with the industry. The following are teacher performance data based on 5 provinces in Indonesia.

Table 1. Teacher Performance in Each Vocational School in 2015/2016

\begin{tabular}{ccccccccc}
\hline \multirow{2}{*}{ No } & Province & \multicolumn{4}{c}{ Conversion Value } & \multicolumn{2}{c}{ Performance } \\
\cline { 3 - 8 } & & \% GL & \% GP & \% GT & \% GPNS & \% GPen & score & Type \\
\hline 1 & DKI Jakarta & 94.57 & 99.26 & 66.45 & 20.05 & 89.07 & 73.9 & Less \\
\hline 2 & West Java & 89.67 & 84.7 & 67.7 & 20.93 & 95.04 & 71.6 & Less \\
\hline
\end{tabular}




\begin{tabular}{rllllllll}
3 & Central Java & 93.56 & 85.27 & 71.43 & 32.32 & 93.91 & 75.3 & Less \\
\hline 4 & East Java & 94.3 & 90.26 & 76.49 & 34.7 & 94.54 & 78.1 & Less \\
\hline 5 & In Yogyakarta & 93.71 & 97.58 & 73.93 & 49.08 & 88.41 & 80.5 & Primary \\
\hline \multicolumn{7}{l}{ Source: Education and Culture Data and Statistics Center, 2016[2] }
\end{tabular}

The review on teacher performance in Table 1.1. Based on several HR indicators consisting of five indicators, including 1) the ratio of principals and eligible teachers (\% KSGL), 2) comparison of principals and female teachers (\% KSGP), 3) comparison of principals and permanent teachers (\% KSGT) , 4) the percentage of school principals and PNS teachers (\% KSGPNS), and 5) the ratio of school principals and retired teachers $(\%$ KSGpen)[2]. Comparative assessment of school principals and teacher's worth teaching (\% KSGL) the standard explanation is that the better the value explains the good quality of the school in terms of the teacher's point of view. The optimum value is $100 \%$ explaining the majority of teachers have the criteria S1 or D4. The benefit is that the criteria for diploma teacher population are the same as the existing law.

Research on the influence of need for achievement, training on teacher performance and competence has been widely carried out. Some research results. In the results of research by Sopandi[3] the competency factor had a positive direction on aspects of the performance of MTS Cipakem Kuningan teachers. This is inversely proportional to the results of Narsih's[4], the results obtained by competency do not affect the performance of teachers of SMKN 23 North Jakarta. In the opinion of experts namely McClelland, Edward Murray, Miller and Gordon W, in Anwar Prabu Mangkunegara concluded that there is a positive relationship between achievement motivation and performance achievement, Saeraya[5] and Hamdani [6].

This is inversely proportional to the findings of Hendro[7], namely achievement motivation or Need For achievement has no effect on teacher performance. This is also in line with Ndapaloka's [8] of the rejection of hypotheses related to need for achievement or encouragement from within the teacher because it is temporary or temporary. And with Markonah and Sunarto's[9] research and Julianry [10] that the higher the motivation, it will not affect the teacher's performance. According to Handoko [11], training is a mastery activity in the aspects of skills and systematic specific work activities clearly and regularly and affects performance in this period. This is not in line with the findings of Sugiarti[12] that training does not affect the performance of PT Padma Ardya Aktuaria Jakarta employees.

Based on the phenomenon of the problems in the above studies regarding the need for achievement, training and performance on performance there are different research results (gap research). Therefore, it is very interesting to conduct research on the effect of need for achievement and training on performance with competence as a mediating variable with a case study of vocational school teachers in Bogor Regency in 2019-2020.

\section{Research Method}

Research design is a concept for collecting, measuring and analyzing data. This research uses a quantitative approach to exploratory studies which often relies on secondary research 
(such as literature reviews). This research will also explain the location of the variables studied and the relationship between one variable with another variable Sekaran \& Bougie[13]. The study used in this study is also a causal study. The teacher holds a very vital function in learning both reflexively with masksud to influence, coaching and developing the potential of students according to Wuandari [14]. Another theory to support is according to Wibowo[15] competence is:"An achievement in carrying out the obligations that are based on competence and knowledge and work ethic in the job". David McClelland stated that individuals who have a need for achievement will pursue satisfaction more than compensation from work. (Grifffin \& Moorhead) [16]. The expert's view according to Dessler [15] training is a procedural way of skills needed by individuals (teachers) to continue their work.

Operational Variable Teacher Performance Nurdin (2002; 91) and the Ministry of National Education [17] a) Implement Learning Programs, b) Implement Learning, c) Implement Evaluations. Competence Moh. Uzer Usman[18] [19]: a) Pedagogic Competencies , b) Personality Competencies , c) Teacher Social Competencies, d) Teacher Professional Competencies .

McClelland's Need For Achievement in Robbins and Judge (2015: 131): a) The drive to excel, b) To achieve in relation to a set of standards, and c) To strive to succeed TrainingDesller [15] a) Instructor , b) Participants , c). Materials d) Methods , e) The objectives of the training.

The population of this research is vocational school teachers in Bogor Regency totaling 2375 teachers. Sampling to be used as a respondent in this study is to use a proposive sampling method by considering the conditions used including the criteria or limits studied and the sample must meet the research criteria. To determine the sample size in this study is to use the Slovin[20] formula model, Husein Umar [21]:

$$
\begin{aligned}
& n=\frac{N}{1+N(e)^{2}} \\
& n=\frac{2375}{1+2375(0,1)^{2}}
\end{aligned}
$$

$\mathrm{n}=96$, thus, the number of samples in this study was determined as much 100 people.

Where :

n: Sample Size

N: Large Population

e: Limit the desired error or disered margin of error

The method of data collection is done through distributing questionnaires to respondents. Questionnaires are efficient data collection mechanisms when studies are descriptive or explanatory (Sekaran \& Bougie)[13]. The method of distributing questionnaires will be done partially by giving questionnaires directly to respondents and distributing questionnaires via electronic mail. Thus this research belongs to the survey method, where researchers use questionnaire instruments to obtain data to research subjects in a relatively short period of time. In this study, the method used to measure is the Likert scale used to measure the attitudes, opinions and perceptions of a person or group of people about social phenomena (Sugiyono) [22]. The Likert scale uses five levels of answers: 5 (strongly agree, 4 (agree), 3 (neutral), 2 (disagree), 1 (strongly disagree). 
Methods of data analysis in research Researchers used quantitative descriptive methods based on the objectives of this study, namely testing hypotheses whose empirical models had more than one dependent variable. Researchers use SEM-PLS, which is a structural equation Model (SEM) based on variance or partial least square (PLS) to test hypotheses. The data analysis technique used is Partial Least Square (PLS). PLS is one of the statistical methods of structural Equational Model (SEM) based variants are designed to complete multiple regression when there is a specific problem in the data, such as the sample size is very small, the data is lost (missing values ) and multikolinearitas (Jogiyanto \& Abdillah) [23]. SEM-PLS is used to develop theories in exploratory research (Hair, Hult, Ringle, \& Sarstedt).[24]

\section{Results and Discussion}

\subsection{Results}

Description of respondents in this study amounted to 100 teachers spread in the Bogor Regency. Characteristics of respondents will be explained based on gender, age, teaching status, length of teaching, School Category and subject areas being taught. Based on the results of the study it can be seen that teachers who are male are 45 people with a percentage of $45 \%$, while female sex is 55 people with a percentage of $55 \%$. Based on the results of this study it can be seen that this study has a dominant respondent at age 23-30 with a percentage of $63 \%$. Then the age of $31-40$ with a percentage of $22 \%$ and aged 41 years and over as much as $15 \%$. Based on the results of the study it can be seen that teachers with PNS status with 14 respondents $(15 \%)$, GTT teachers with 23 people $(23 \%)$ and Honor teachers with 63 people $(63 \%)$. Indicates that the majority of teachers currently reside and remain in one school with permanent status and contracts. Teachers with tenure under five are 62 people $(62 \%)$, teachers with 5 to 10 years are 21 people $(21 \%)$ and teachers with tenure over 10 years are 17 people (17\%). With different working periods, there is a cultural and information exchange in teaching at school.

The teacher, if divided into three groups, namely national content teacher, regional content teacher and vocational teacher (Productive) in accordance with Perdirjen Dikdasmen no 464 in 2018. National content is the subject of religious education, citizenship education, Indonesian language, English language, mathematics and history Indonesia. Territorial content includes cultural arts, PJOK and Sundanese language and or other foreign languages. Whereas the vocational content consists of areas of expertise, expertise programs and expertise competencies. These include physics, chemistry, digital simulation and vocational productive subjects. Teachers with national content dominated as many as 47 people (47\%), territorial content 8 people $(8 \%)$ and vocational content 45 people $(45 \%)$. Maybe this is caused by the clustering of Vocational High Schools so that they are dominated by national and vocational content teachers.

\subsubsection{Structural Equation Modeling (SEM)}

The loading factor value used in this study is $\geq 0.5$, so that the correct and / or consistent reality is obtained. If in the test found indicators on each variable that is $\leq 0.5$, it will be removed from the model and made the latest adjustments. Convergent Validity testing of the measurement model with reflexive indicators is assessed based on the correlation between item scores or component scores and construct scores calculated with PLS. Individual 
indicators are considered valid if they have a correlation value above 0.70 . However, at the scale development research stage, loading factors of 0.50 to 0.60 are still acceptable

Table 2. Mean and outer models

\begin{tabular}{|c|c|c|c|c|c|c|c|c|c|c|}
\hline \multirow{2}{*}{ Indicator } & \multirow{2}{*}{$\begin{array}{l}\text { The } \\
\text { mean }\end{array}$} & \multicolumn{5}{|c|}{ Outer loading } & \multicolumn{4}{|c|}{ Cross loading } \\
\hline & & $N F A$ & $P P$ & $K K$ & $K G$ & NFA & P P & K K & K G. & Information \\
\hline The drive to excel & 3.70 & 0.883 & & & & 0.883 & 0.495 & 0.48 & 0.428 & Valid \\
\hline $\begin{array}{l}\text { to achieve in } \\
\text { relation to a set of } \\
\text { standards }\end{array}$ & 3.9 & 0737 & & & & 0.598 & 0.45 & 0.48 & 0.30 & Invalid \\
\hline $\begin{array}{l}\text { To strive to } \\
\text { succeed }\end{array}$ & 3.80 & 0.751 & & & & 0.751 & 0.456 & 0.305 & 0.342 & Valid \\
\hline Instructor & 3.94 & & 0769 & & & 0.347 & 0769 & 0.45 & 0.398 & Valid \\
\hline Participant & 3.75 & & 0.791 & & & 0.432 & 0.791 & 0.408 & 0.507 & Valid \\
\hline Theory & 3.69 & & 0769 & & & 0.536 & 0769 & 0.454 & 0.421 & Valid \\
\hline Method & 3.69 & & 0.809 & & & 0.473 & 0.809 & 0.473 & 0.353 & Valid \\
\hline $\begin{array}{l}\text { Training } \\
\text { objectives }\end{array}$ & 3.93 & & 0843 & & & 0.509 & 0843 & 0.469 & 0.46 & Valid \\
\hline $\begin{array}{l}\text { Pedagogical } \\
\text { Competence }\end{array}$ & 4.14 & & & 0.756 & & 0.595 & 0.615 & 0.756 & 0.527 & Valid \\
\hline $\begin{array}{l}\text { Personality } \\
\text { competence }\end{array}$ & 4.55 & & & 0.739 & & 0.212 & 0.341 & 0.739 & 0.408 & Valid \\
\hline $\begin{array}{c}\text { Teacher Social } \\
\text { Competence } \\
\text { Teacher }\end{array}$ & 4.49 & & & 0.768 & & 0.271 & 0306 & 0.768 & 0.484 & Valid \\
\hline $\begin{array}{l}\text { Professional } \\
\text { Competencies }\end{array}$ & 4.46 & & & 0.811 & & 0.328 & 0.393 & 0.811 & 0.558 & Valid \\
\hline $\begin{array}{l}\text { Implement } \\
\text { Learning } \\
\text { Programs }\end{array}$ & 4.14 & & & & 0826 & 0.416 & 0.45 & 0.527 & 0.826 & Valid \\
\hline $\begin{array}{c}\text { Learning } \\
\text { Implementation }\end{array}$ & 4.35 & & & & 0.89 & 0.424 & 0.481 & 0.594 & 0.89 & Valid \\
\hline $\begin{array}{l}\text { Evaluation } \\
\text { Implementation }\end{array}$ & 4.19 & & & & 0.735 & 0.311 & 0.381 & 0.466 & 0.735 & Valid \\
\hline
\end{tabular}

Source: Processed products using SmartPLS 03.2020

Note: NFA $=$ Need for Achievement

$$
\begin{aligned}
& \mathrm{PP}=\text { Training } \\
& \mathrm{KK}=\text { Competence } \\
& \mathrm{KG}=\text { Performance }
\end{aligned}
$$

Due to the smallest loading factor value in the dimension to achieve in relation to a set of standards and the effect on Average Variance Extracted (AVE) due to a limit of 0.70, the dimension is removed from the loading factor.

\subsubsection{Confirmatory Factor Analysis (Confirmatory Factor Analysis / CFA)}

Table 3. AVE, Fornell-Larcker-Criterium (Square Root AVE) and Construct Reliability

\begin{tabular}{cccccccc} 
Variable & $\begin{array}{c}\text { AVE } \\
\text { value }\end{array}$ & \multicolumn{3}{c}{ Fornell- Larcker-Criterium (Square } \\
Root AVE) & KK & KG & $\begin{array}{c}\text { Cronbach's } \\
\text { Alpha }\end{array}$ & $\begin{array}{c}\text { Composite } \\
\text { reliability }\end{array}$ \\
\hline NFA & 0.672 & 0819 & & & & 0.521 & 0.802 \\
PP & 0.635 & 0.578 & 0.797 & & & 0.856 & 0.887
\end{tabular}




\begin{tabular}{llllllll} 
KK & 0.591 & 0.491 & 0.565 & 0769 & & 0.775 & 0.853 \\
KG & 0.665 & 0.474 & 0.539 & 0.652 & 0.816 & 0.746 & 0.856 \\
\hline
\end{tabular}

All indicators of the variable construct have higher values than the other constructs. An indicator is declared valid by discriminant validity if it has the highest cross loading to the intended construct compared to cross loading to other constructs. Thus, latent constructs predict indicators in their blocks better than indicators in other blocks. This concludes that the suitability of an indicator is compared with other constructs such as need for achievement, training and competence.

\subsubsection{Reliability and Goodness of Fit Test}

Table 4. Inner model: Test the feasibility of the model

\begin{tabular}{lllll}
\hline Variable & $\begin{array}{l}\text { R- } \\
\text { Square }\end{array}$ & R-square adj & Q2 & GoF \\
\hline $\begin{array}{l}\text { Teacher } \\
\text { performance }\end{array}$ & 0.478 & 0.462 & 0.66592 & 0.235 \\
Competence & 0.36 & 0.347 & & \\
\hline
\end{tabular}

Source: The results of data management using SmartPLS 03.2020.

Based on the above results the value of $\mathrm{R}$-square, $\mathrm{R}$-square adj, predictive relevance $\left(\mathrm{Q}^{2}\right)$ and GoF in this study a value $\geq 0.05$ so that it can be drawn a conclusion that the independent variable in accordance with the dependent variable, in other words that this model has predictive relevance that well.

\subsection{Discussion}

\subsubsection{Hypothesis test}

Table 5. Hypothesis Testing Results

\begin{tabular}{|c|c|c|c|c|c|c|}
\hline & $\begin{array}{l}\text { Original } \\
\text { Sample (O) }\end{array}$ & $\begin{array}{l}\text { Sample } \\
\text { mean }(M)\end{array}$ & $\begin{array}{l}\text { Standard } \\
\text { deviation } \\
\text { (STDEV) }\end{array}$ & $\begin{array}{l}\text { T Statistics } \\
(\mathrm{O} \\
\text { STDEV) }\end{array}$ & $\begin{array}{l}\text { Bidirectional } \\
\text { T-table (n-k) } \\
0.025 \% \\
\end{array}$ & $\begin{array}{l}P \text { values } \\
<0.05\end{array}$ \\
\hline $\begin{array}{l}\text { Need For Achievement } \\
\text { (X1) -> Teacher } \\
\text { performance (Y2) }\end{array}$ & 0.125 & 0.115 & 0.096 & 1,302 & 1.98 . & 0.193 \\
\hline $\begin{array}{l}\text { Training } \quad \text { (X2) }-> \\
\text { Teacher } \\
\text { (Y2) }\end{array}$ & 0.196 & 0.199 & 0.091 & 2,154 & 1.98 . & 0.032 \\
\hline $\begin{array}{l}\text { Need For Achievement } \\
\text { (X1) } \rightarrow>\text { Competence } \\
\text { (Y1) }\end{array}$ & 0.247 & 0.249 & 0.087 & 2,839 & 1.98 . & 0.005 \\
\hline $\begin{array}{l}\text { Training (X2) } \quad-> \\
\text { Competence (Y1) }\end{array}$ & 0.422 & 0.431 & 0.094 & 4,489 & 1.98 . & 0,000 \\
\hline $\begin{array}{l}\text { Competencies (Y1) -> } \\
\text { Teacher performance } \\
\text { (Y2) }\end{array}$ & 0.480 & 0.493 & 0.083 & 5783 & 1.98. & 0,000 \\
\hline $\begin{array}{l}\text { Need For Achievement } \\
\text { (X1) -> Competence } \\
\text { (Y1) -> Teacher } \\
\text { performance (Y2) }\end{array}$ & 0.119 & 0.122 & 0.045 & 2,644 & 1.98. & 0.008 \\
\hline
\end{tabular}




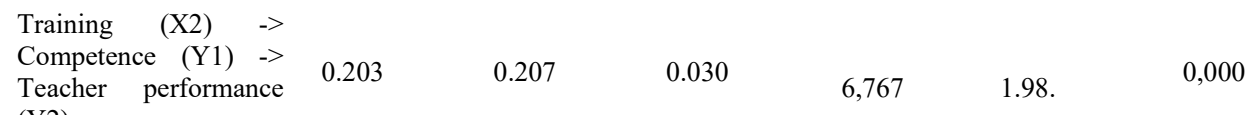

Teacher performance

(Y2)

Source: The results of data management using SmartPLS 03.2020.

The statistical calculation obtained from table 1.5 is to answer the following hypothesis:

a. Hypothesis $1-$ need for achievement on teacher performance

b. Obtained path coefficient of 0.125 and $\mathrm{T}_{\text {arithmetic }}(1.302)<\mathrm{T}$ table $(1.98)$ with $p$-values of 0.193 , thus $\mathrm{H}_{1}$ is rejected ( $\left.p>0.05\right)$, need for achievement has no effect on teacher performance

c. Hypothesis 2 -training on teacher performance

Path coefficients obtained for 0196 and $\mathrm{T}_{\text {count }}(2154)>\mathrm{T}_{\text {table }}(1.98)$ with $p$-values of 0.032, thus the $\mathrm{H}_{2}$ is received $(p<0.05)$, training has a positive effect on the performance of teachers.

d. Hypothesis 3 - need for achievement on competence

Retrieved path coefficient of 0.247 and $\mathrm{T}_{\text {count }}(2839)>\mathrm{T}$ table (1.98) with $p$-values of 0.005 , thus $\mathrm{H}_{3}$ is received $(p<0.05)$, need for achievement has a positive effect on the competence

e. Hypothesis 4 - training on competency

Path coefficients obtained for 0422 and $\mathrm{T}_{\text {count }}(4489)>\mathrm{T}_{\text {table }}(1.98)$ with $p$-values of 0.000 , thus $\mathrm{H}_{4}$ is received $(p<0.05)$, positive effect on competency training

f. Hypothesis 5 -competence on teacher performance

Path coefficients obtained for 0480 and $\mathrm{T}_{\text {count }}(5783)>\mathrm{T}_{\text {table }}(1.98)$ with $p$-values of 0.0000 , thereby $\mathrm{H}_{5}$ received $(p<0.05)$, competence positive effect on the performance of teachers.

g. Hypothesis 6 -Competence is able to mediate the effect of need for achievement on teacher performance.

Retrieved path coefficient of 0.119 and $\mathrm{T}_{\text {count }}(2644)>\mathrm{T}_{\text {table }}(1.98)$ with $p$-values of 0.008 , thus $\mathrm{H}_{6}$ is received $(p<0.05)$, Competence capable of mediating influence of need for achievement on teacher performance. (Full Mediation)

h. Hypothesis 7 -Competence is able to mediate the effect of training on teacher performance.

Path coefficients obtained for 0203 and $\mathrm{T}_{\text {count }}(6767)>\mathrm{T}_{\text {table }}(1.98)$ with $p$-values of 0.0000 , thereby $\mathrm{H}_{7}$ received $(p<0.05)$, Competence capable of mediating the effect of training on teacher performance (Partial Mediation)

\section{Conclusions}

This is in line with Wibowo's research [7] that motivation is not affect performance due to motivation due to the appearance of several deviations in performance, among others, laxity / violence, central tendency and assessment with a perverted impression. This is in line with the research of Ndapaloka [8]. Reasons for rejection of the hypothesis this is because it relates to the need for achievement or encouragement from within the teacher himself through certain training and courses. The teacher hasn't done challenging activities, choose activities with an easy difficulty level and avoid difficult assignments. This is in line with the research of Gala et al [25], Novianti[26] and Sukowati et al [27]. Training is carried out for 
teachers so they can carry out their task's new assignments and for old teachers to improve the quality of learning in this case the current and future performance. This proves that the results of this study are consistent and support previous research.

This is in line with research from Widya Yuliana et al [28], Kahpi et al [29], and Suryadana [30], the higher the achievement motivation of a teacher, the better the competencies they have. This proves that the results of this study are consistent and support previous research. This is in line with research conducted by Pranata et al[31], Prasetyo and Nurnida[32], Mokhtar and Susilo[33], Kahpi et al[29] and Mokhtar and Heru[34], that job training variables have a significant effect on variables. competency of employees (teachers) where the higher the success of implementing job training programs for employees, the higher the increase in competence employee (teacher).

This is in line with research from Sopandi[3], Manik and Syafrina[35], Supriyono (2017), and Saputra et al[36] state that individual performance is influenced by competency factor, the higher the employee competency, the higher the performance achieved. This proves that the results of this study are consistent and supportive previous research. This is in line with research from Anam and Prasetyo[37], Saragih [5],Soetopo [38] and M. Hafid [39]. By understanding this all is certainly an effort can be done in improving teacher performance by increasing motivation achievement (need for achievement) and teacher competence, so as to improve teacher performance which in the end is able to create good learning.

This is in line with research conducted by Pranata et al[31], Prasetyo and Nurnida[32] (2017), Kahpi [29] and Soetopo[38]. employee training has plenty of time to do the job properly, following the training of a teacher who is mostly in the working period with a span of 0-5 years getting additional new work experience that can increase a person's competence teachers in meeting job demands according to competency and knowledge needs.

Based on the conclusions above, several suggestions can be put forward for consideration by educational institutions and for further research:

Suggestions for educational institutions that the need for achievement or achievement motive for vocational teachers cannot be achieved, given the level of motivation in vocational teachers is still at the stage of physiological needs, so that in themselves there is no idealism for teaching by targeting the criteria for the results to be achieved. Instructors in training are tailored to the needs in the world of education. Suggestions for further researchers to be able to further develop variables and indicators that have not been used in this study, especially variables that are not significant, for example by adding compensation variables, work discipline or workload.

\section{References}

[1] R. Indonesia, "Undang-Undang Nomor 20 Tahun 2003 tentang Sistem Pendidikan Indonesia," indonesia. 2003.

[2] Kemendikbud, "Indonesia education statistics in brief 2015/2016," Cent. Educ. Data Stat. Cult., 2016.

[3] A. Sopandi, "Pengaruh Kompetensi Profesional dan Kompetensi Kepribadian Terhadap Kinerja Guru," Sci. J. Reflect., 2019.

[4] D. Narsih, "Pengaruh Kompetensi dan Kepuasaan Kerja terhadap Kinerja Guru SMKN 23 Jakarta Utara," J. Ilm. Pendidik. dan Ekon., 2017.

[5] T. Saeraya and R. Saragih, "Pengaruh Motivasi Kerja Terhadap Kinerja Karyawan Di Pt Pln ( Persero ) Apj Bandung," e-Proceeding Manag., 2018.

[6] Hamdani, N. Kesumawati, and M. Kristiawan, "The Influence of Teachers 'Work Motivation and Principals' Managerial Competence on Teachers' Performance,” J. Humanit. Soc. Sci., 
2018.

[7] D. H. Wibowo, "MOTIVASI BERPRESTASI DALAM KAITANNYA DENGAN KINERJA GURU," Sch. J. Pendidik. dan Kebud., 2015, doi: 10.24246/j.scholaria.2015.v5.i3.p65-74.

[8] V. Ndapaloka, W. Hardyanto, and T. Prihatin, "Pengaruh Supervisi Akademik Pengawas Dan Kepemimpinan Kepala Sekolah Melalui Motivasi Berprestasi Sebagai Mediasi Terhadap Kinerja Guru SMK Negeri Kabupaten Ende,” Educ. Manag., 2016.

[9] ส. ไทรทับทิม, "No Titleการนำสาหร่ายที่ผลิตน้ำมันไบโอดีเซลมาบำบัดน้ำเสียของ โรงงานอุตสาหกรรมรีไซเคิล," pp. 1-20, 2554, [Online]. Available: http://library1.nida.ac.th/termpaper6/sd/2554/19755.pdf.

[10] A. Julianry, R. Syarief, and M. J. Affandi, "Pengaruh Pelatihan dan Motivasi Terhadap Kinerja Karyawan serta Kinerja Organisasi Kementerian Komunikasi dan Informatika," J. Apl. Bisnis dan Manaj., 2017, doi: 10.17358/jabm.3.2.236.

[11] T. H. Handoko, Manajemen Personalia dan Sumber Daya Manusia. 2011.

[12] Sugiarti, T. Hartati, and H. Amir, "Pengaruh Pelatihan Kerja terhadap Kinerja Karyawan pada PT Padma Ardya Aktuaria Jakarta," J. Epigram Vol. 13 No. 1 April, 2016.

[13] U. Sekaran and R. Bougie, "Research Method for Business Textbook: A Skill Building Approach," John Wiley Sons Ltd., 2016.

[14] P. K. Pedagogik and K. Sosial, "Jurnal SWOT , Volume VIII , No 1, Januari 2018 Jurnal SWOT , Volume VIII , No 1, Januari 2018," vol. VIII, no. 1, pp. 13-26, 2018.

[15] G. Dessler, "Manajemen Sumber Daya Manusia," in Pelatihan dan Pengembangan, 2017.

[16] G. Moorhead and R. W. Griffin, Perilaku Organisasi Manajemen Sumber Daya Manusia dan Organisasi (Diana Angelica, Penerjemah.). 2013.

[17] Republik Indonesia, “Undang-Undang Nomor 14 Tahun 2005 tentang Guru dan Dosen," Sekr. Negara, 2005.

[18] A. Majid, Perencanaan Pembelajaran Mengembangkan Kompetensi Guru. 2013.

[19] Republik Indonesia, Peraturan Pemerintah R.I. Nomor 19 Tahun 2005, Standar Nasional Pendidikan, Pasal 6, Ayat (1). 2005.

[20] A. Hidayat, "Cara Hitung Rumus Slovin Besar Sampel," Statistikian, 2017. .

[21] H. Umar, "Penelitian Kuantitatif Langkah Demi Langkah," Pelatih. Metodol. Penelit. Kopertis III, 2012.

[22] Sugiyono, "Metode Penelitian Bisnis (Pendekatan Kuantitatif, Kualitatif, Kombinasi dan R\&D)," in Metodelogi Penelitian, 2017.

[23] W. Abdillah and H. Jogiyanto, "Partial Least Square (PLS) Alternatif Structural Equation Model (SEM) dalam Penelitian Bisnis", Edisi I, Yogyakarta: Andi. 2019.

[24] M. Hair, J. F., Hult, G. T. M., Ringle, C. M., \& Sarstedt, "A Primer on Partial Least Squares Structural Equation Modeling (PLS-SEM). Thousand Oaks," Sage, 2013.

[25] I. N. Gala, H. A. Ramadhan, and A. Rede, "Pengaruh Pelatihan Dan Motivasi Kerja Terhadap Kinerja Mengajar Guru Ipa Di Smp Se-Kota Poso,” 2017.

[26] N. E. R. Lestari, "Pengaruh Pendidikan, Dan Pelatihan Karyawan Terhadap Kinerja Karyawan Pada Kementerian Pekerjaan Umum Dan Perumahan Rakyat/Pupr,” Hilos Tensados, 2019.

[27] Sukowati, Afrizal, and Wargianto, "Pengaruh Disiplin Kerja, Komitmen Organisasi dan Pelatihan Terhadap Kinerja yang Berdampak Kepada Prestasi Kerja,” J. Ekon. dan Manaj. STIE Pertiba Pangkalpinang, 2018.

[28] Yuliana, Haryadi, and A. I. Anggraeni, "Pengaruh Kompetensi Dan Pelatihan Guru Terhadap Profesionalisme Guru Dengan Motivasi Sebagai Variabel Intervening Di Mi,Mts Dan Smk Yayasan Pesantren Darul Abror Kedungjati,” J. Ekon. Bisnis, dan Akunt., 2019.

[29] H. S. Kahpi, A. Khurosaini, and I. Suhendra, "Pengaruh Pelatihan dan Motivasi Berprestasi Terhadap Kinerja Pegawai Dengan Kompetensi Sebagai Variabel Intervening,” J. Ris. Bisnis dan Manaj. Tirtayasa, 2017.

[30] I. Vol, "Peranan motivasi berprestasi terhadap kompetensi dan kepuasan kerja pegawai," pp. 65-75, 2016.

[31] O. S. Pranata, E. S. Astuti, and H. N. Utami, "Pengaruh Pelatihan Terhadap Kompetensi dan Kinerja Karyawan (Studi Pada Karyawan Tetap di PT Bank Tabungan Pensiunan Nasional Syariah Malang Divisi Mobile Marketing Syariah ),” J. Adm. Bisnis, 2018. 
[32] A. I. Prasetyo and I. Nurnida, "Analisis Pengaruh Pendidikan Dan Pelatihan Terhadap Kinerja Melalui Kompetensi," Ecodemica, 2017.

[33] N. R. Mokhtar and H. Susilo, "Pengaruh Pelatihan Terhadap Kompetensi,” J. Adm. Bisnis, 2017

[34] N. R. Mokhtar and H. Susilo, "PENGARUH PELATIHAN TERHADAP KOMPETENSI (Penelitian tentang Pelatihan pada Calon Tenaga Kerja Indonesia di PT Tritama Bina Karya Malang)," J. Adm. Bisnis S1 Univ. Brawijaya, 2017.

[35] S. Manik and N. Syafrina, "PENGARUH KOMPETENSI TERHADAP KINERJA DOSEN SEKOLAH TINGGI ILMU EKONOMI RIAU,” J. Ilm. Ekon. Dan Bisnis, 2018, doi: 10.31849/jieb.v15i1.72.

[36] I. Putu, A. Saputra, W. Bagia, W. Suwendra, and J. Manajemen, "PENGARUH KOMPETENSI DAN DISIPLIN KERJA TERHADAP KINERJA KARYAWAN," 2016.

[37] M. S. Anam and I. Prasetyo, "Pengaruh Pelatihan Peningkatan Kompetensi dan Motivasi terhadap Kinerja Guru SMKN 4 Bojonegoro,” MAP (Jurnal Manaj. dan Adm. Publik), 2019.

[38] M. P. Soetopo, "Pengaruh kepemimpinan, pendidikan dan pelatihan motivasi kerja, dan budaya organisasi terhadap kompetensi dan kinerja guru," J. STEI Ekon., 2016.

[39] M. Hafid, "Pengaruh Motivasi dan Kompetensi Guru Terhadap Kinerja Guru Sekolah dan Madrasah di Lingkungan Pondok Pesantren Salafiyah Syafi'iyah Sukorejo,” J. Pendidik. Islam Indones., 2017, doi: 10.35316/jpii.v1i2.55. 